\title{
Performance of Grass Filter Strip in Copper and Zinc Removal in Surface and Subsurface Runoff
}

\author{
Weijie Huo ${ }^{1}$, Huaidong Zhou' ${ }^{1}$, Linghua Liu' ${ }^{1}$, Gaofeng Zhao', Zhaohui Yang ${ }^{2}$ and Yilei Yu ${ }^{3}$ \\ ${ }^{1}$ Department of water environment, China Institute of Water Resources and Hydropower Research, Beijing, China, 100038 \\ ${ }^{2}$ State Key Laboratory of Simulation and Regulation of River Basin Water Cycle, China Institute of Water Resources and Hydropower \\ Research, Beijing, China, 100038 \\ ${ }^{3}$ Beijing Key Laboratory of Wetland Services and Restoration , Institute of Wetland Research, Chinese Academy of Forestry, Beijing, China, \\ 100091
}

\begin{abstract}
Three filter strips were conducted on self-designed soil bins. Taking a filter strip with no vegetation as contrast, the effectiveness of vegetation and soil conditions on heavy metals (including copper and zinc) removal efficiencies were investigated by simulated runoff experiment. The results showed that the adsorbed state is the main existing form of heavy metal. For surface runoff, most of total copper and total zinc are trapped in first $4 \mathrm{~m}$ and it is ineffective to increase the distance beyond $4 \mathrm{~m}$ for removal. Vegetation has no significant effect on total copper and total zinc removal, while the soil with higher content of organic matter is contributing to total $\mathrm{Zn}$ interception. For subsurface runoff, the removal efficiencies of total copper and total zinc can reach to above $95.38 \%$ and both vegetation and soil conditions have no significant effects. Vegetation is contributing to copper ion and zinc ion removal significantly. Soil condition is only a significant factor to zinc ion, with higher content of organic matter as a contributing factor.
\end{abstract}

\section{Introduction}

Even Intensive agriculture has sustained the world development, but some agricultural activities are contributing to the environmental health decreases at local, regional, and global scales. In China, the contaminants discharged in key river basins from agriculture are much more than from industry [1]. The excess sediment, nutrient and heavy metals from agricultural runoff have been a major cause to water quality deterioration.

Vegetative filter strip here is defined as a band of soil planted with permanent vegetation, and when the cropland runoff flows across the area, it undergoes a decrease of pollutant concentration and volume. Over the past decades, numerous studies have shown that it is a proposing way to attenuate sediment and nutrient in cropland run off [2-6].

Vegetative filter strip can disperse current and reduce the velocity of runoff and promote sedimentation, infiltration and adsorption. Vegetation plays an important role, such as soil conservation, biological utilization, improving soil permeability. The vegetation types used in studies include perennial grasses [7-11], shrubs [12-14], forests $[15,16]$ and combinations of those above.

Compared to forest and shrub, grass filer strip is still economical alternative to reduce non-point source pollutants, and particularly those native grasses with tall, erect and stiff stems and strong root systems, is highly valued for removing particulate contaminants. Fescue is a common choice to construct grass filter strip, which is a kind of tufted grasses with strong fibrous root system, and widely used for buffer zones. In a field experiment, Daniels found that the fescue filter strip reduced runoff load by $50 \sim 80 \%$, TSS by $80 \%$, TP by $50 \%$ and retained NH4+-N by $20 \sim 50 \%$ [17]. Under simulated rainfall conditions, Magette found that the Kentucky-31 fescue filter strips were effective to remove nutrient in runoff [7]. Another study compared three practices, and reported that the fescue strip with switchgrass barrier was the most effective to reduce losses of organic $\mathrm{N}, \mathrm{NO}_{3}{ }^{-} \mathrm{N}, \mathrm{NH}_{4}{ }^{+}-\mathrm{N}$, $\mathrm{PP}$ and $\mathrm{PO}_{4}{ }^{3-}-\mathrm{P}$ [8]. These studies have shown the effect of tall fescue filter strip on contaminants removal successfully.

Besides vegetation, soil condition is also an important factor to the effect of filter strip. The component, porosity, and texture of soil are usually positively correlated with precipitation volume and removal efficiency of pollutant.

Heavy metal pollution is long lasting, irreversible and it is hard to give rid of its influence once it is introduced into environment. It can harm human health and ecosystem safety through food chain. However, the studies on heavy metal attenuation by vegetative filter strips have been fewer.

The objectives of this study were : (i) to compare copper $(\mathrm{Cu})$ and zinc $(\mathrm{Zn})$ removal efficiencies by 
contrast filter strip, tall fescue filter strips with different soils, (ii) to estimate the effects of vegetation and soil on total heavy metals and heavy metal ions removal in surface runoff and subsurface runoff.

\section{Materials and methods}

\subsection{Construction of experimental system}

Experimental system is consisted of PE bucket and soil bin system. The volume of PE bucket is $800 \mathrm{~L}$, and water is controlled by flow meter. Soil bin system is consisted of drainage channel and soil bin. Drainage channel is $7.5 \times 10^{-2} \mathrm{~m}^{3}$ (Length $0.3 \mathrm{~m} *$ width $0.5 \mathrm{~m} *$ high $0.5 \mathrm{~m}$ ), while soil bin is $1.5 \mathrm{~m}^{3}$ (long $6.0 \mathrm{~m} *$ width $0.5 \mathrm{~m} *$ high $0.5 \mathrm{~m})$. Water from PE bucket flows firstly into the drainage channel, and then enters into soil bin by horizontal overflow. There are three surface holes along the bin of $2 \mathrm{~m}, 4 \mathrm{~m}$ and $6 \mathrm{~m}$ (No.01, 03 and 05), and three bottom holes (No.02, 04 and 06) corresponding to surface holes vertically. The soil bin is placed on the bracket with adjustable slope, and the structure is shown in Figure 1.

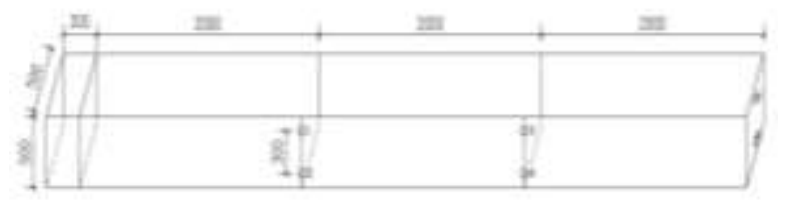

Figure 1. Sketch Map of Soil Bin System (unit: mm).

Soil bin is filled with soil of $0.35 \mathrm{~m}$ depth. There are three filter strips constructed on three soil bins. The set is as follows: $\mathrm{C}$ is a contrast filter strip with no plant in it, and $1 \#$ soil is filled in. A is a tall fescue filter strip with $1 \#$ soil filled in. The tall fescue grows with coverage $90 \%$, average root length of $35 \mathrm{~cm}$, average tissue height aboveground of $42 \mathrm{~cm}$, fresh weight of $4.11 \mathrm{~kg} \mathrm{~m}^{-2}$, dry weight of $0.721 \mathrm{kgm}^{-2}$. B is also a tall fescue filter strip with $2 \#$ soil filled in. The tall fescue grows with coverage around $90 \%$, average root length of $36 \mathrm{~cm}$, average tissue height aboveground of $40 \mathrm{~cm}$, fresh weight of $4.76 \mathrm{~kg} \mathrm{~m}^{-2}$, dry weight of $0.913 \mathrm{~kg} \mathrm{~m}^{-2}$. The main physical and chemical properties of $1 \#$ and $2 \#$ soil are listed in Table 1 . According to the soil mechanical composition data and international standard of soil texture classification, 1\# soil is specified as silt loam, while $2 \#$ soil is specified as clay loam [18].

Table 1. The main physical and chemical properties of the tested soil.

\begin{tabular}{|c|c|c|c|c|c|c|c|}
\hline $\begin{array}{c}\text { Soil } \\
\text { No. }\end{array}$ & $\begin{array}{c}\text { organic } \\
\text { matter }\end{array}$ & $\mathrm{Cu}$ & $\mathrm{Zn}$ & $\mathrm{CEC}$ & \multicolumn{3}{|c|}{ particle composition\% } \\
\hline & $\mathrm{g} \mathrm{Kg}^{-1}$ & \multicolumn{2}{|c|}{$\mathrm{mg} \mathrm{Kg}^{-1}$} & $\begin{array}{c}\mathrm{cmol}^{+} \\
\mathrm{Kg}^{-1}\end{array}$ & sand & $\begin{array}{c}\text { powd } \\
\text { er }\end{array}$ & clay \\
\hline $1 \#$ & 5.64 & 25.1 & 156 & 3.41 & 70.96 & 26.00 & 3.04 \\
\hline $2 \#$ & 18.25 & 18.2 & 59.0 & 12.5 & 61.83 & 20.76 & 17.41 \\
\hline
\end{tabular}

Note: The unit of CED is $\mathrm{cmol}^{+} \mathrm{Kg}^{-1}$, which is positive charge per kilogram.

\subsection{Experimental scheme}

Experimental devices are located on the bank of Kunyu River, near $\mathrm{Yu}$ Yuan Tan park, in Beijing, China. Simulated runoff experiments are applied. Experimental water is extracted from river into bucket $(800 \mathrm{~L})$, and soil particles and concentrated solutions of heavy metal $(\mathrm{Cu}$, $\mathrm{Zn})$ are accurately added into bucket according to the experimental design, which is to simulate the sand and heavy metal in cropland runoff.

Grouped comparison is applied. Vegetation effect is investigated by contrast filter strip versus tall fescue filter strip $(C$ versus $A)$. Soil condition effect is investigated by soil 1 \# versus soil 2\#(A versus B).

Since the start of the simulation runoff, system inlet water samples from outlet of bucket are collected by every 10-15 minutes. Surface runoff samples from surface holes along the bin of $2 \mathrm{~m}, 4 \mathrm{~m}$ and $6 \mathrm{~m}$ are collected. Subsurface runoff samples from bottom holes along the bin of $2 \mathrm{~m}, 4 \mathrm{~m}, 6 \mathrm{~m}$ are also collected. The concentrations of heavy metals are determined immediately after collection.

Heavy metal determined in this study is divided into total amount of heavy metals and heavy metal ions. The concentration of total amount was determined by total water sample acid digestion. Briefly, a volume of $15 \mathrm{~mL}$ of total water sample was weighed. About $1.5 \mathrm{~mL}$ concentrated $\mathrm{HNO}_{3}$ was added to sample and the sample was heated to concentrate into $2-5 \mathrm{ml}$. Then $1.5 \mathrm{ml} \mathrm{HNO}_{3}$ and $0.2 \mathrm{~mL} \mathrm{H}_{2} \mathrm{O}_{2}$ were added into that concentrated solution. Then it continues to concentrate into $1 \mathrm{ml}$. Lastly, ionized water is added to sample until the volume to $25 \mathrm{~mL}$. Determination of heavy metal ions is directly to use the water sample that is filtered by $0.45 \mu \mathrm{m}$ membrane. All the heavy metal concentrations determination is completed by ICP-MS(Perkin-Elmer, USA). $\mathrm{HNO}_{3}$ and $\mathrm{H}_{2} \mathrm{O}_{2}$ used in experiment are guarantee reagent. Parallel sample determination should be done for ensure the precision of the experiment. The relative standard deviations of heavy metals were less than $5 \%$.

\section{Results and analysis}

\subsection{Analysis of interception characteristics of heavy metals in surface runoff}

Heavy metal existing in runoff water and sediment is generally divided into particulate and dissolved fractions by filter through a $0.45 \mu \mathrm{m}$ membrane. Heavy metals ion may be combined with the active groups of soil particles by adsorption, and may get into water by desorption. Heavy metal ion exists in the balance of adsorption and desorption. $\mathrm{Cu}$ and $\mathrm{Zn}$ are chosen as target pollutants and their interception features are investigated by surface runoff and subsurface runoff.

Heavy metal determination in surface runoff is total amount determination, including adsorbed heavy metals combined with suspended matter, as well as heavy metal ion with reactive activity that dissolved in water. Total $\mathrm{Cu}$ removal efficiencies in surface runoff are shown in Figure 2. 


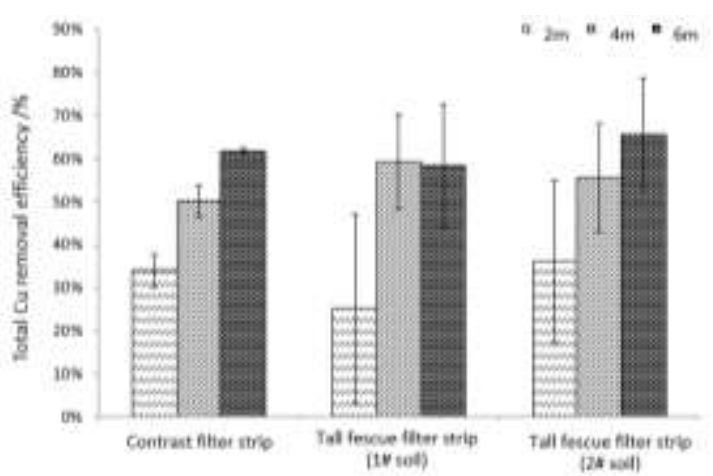

Figure 2. Total $\mathrm{Cu}$ removal efficiencies in surface runoff along $2 \mathrm{~m}, 4 \mathrm{~m}$, and $6 \mathrm{~m}$ of strip.

Total $\mathrm{Cu}$ removal efficiencies of contrast filter strip with $2 \mathrm{~m}, 4 \mathrm{~m}$ and $6 \mathrm{~m}$ are $33.89 \%, 50.13 \%$ and $61.61 \%$ successively. Total $\mathrm{Cu}$ removal efficiencies of tall fescue filter (1\# soil) are $25.09 \%, 59.19 \%$ and $58.30 \%$ successively. Total $\mathrm{Cu}$ removal efficiencies of tall fescue filter (2\# soil) are $36.00 \%, 55.47 \%$ and $65.42 \%$. The result is shown that the total $\mathrm{Cu}$ removal efficiencies of all filter strips have the trend of increasing with the filter width increasing. Comparing the total $\mathrm{Cu}$ removal efficiencies along $2 \mathrm{~m}, 4 \mathrm{~m}$, and $6 \mathrm{~m}$ of filter strip, that of $4 \mathrm{~m}$ is significantly higher than that of $2 \mathrm{~m}$, and the removal is slowing down with width increasing from $4 \mathrm{~m}$ to $6 \mathrm{~m}$. Therefore, $0-4 \mathrm{~m}$ is considered to be the main strip width of $\mathrm{Cu}$ interception.

Adopting the method of spss 17.0 one-way analysis of variance to compare the $\mathrm{Cu}$ removal efficiency of $6 \mathrm{~m}$ filter strip, it is found that there is no significant difference $(p=0.753)$ between contrast filter strip and tall fescue filter strip (A with $1 \#$ soil). And there is no significant difference $(p=0.562)$ between tall fescue filter strip with $1 \#$ soil (A) and tall fescue filter strip with $2 \#$ soil (B). Therefore, the vegetation condition and soil condition are not significant factors to $\mathrm{Cu}$ removal efficiency.

Total $\mathrm{Zn}$ removal efficiencies in surface runoff along $2 \mathrm{~m}, 4 \mathrm{~m}$, and $6 \mathrm{~m}$ are shown in Figure 3. Total $\mathrm{Zn}$ removal efficiencies of contrast filter strip with $2 \mathrm{~m}, 4 \mathrm{~m}$ and $6 \mathrm{~m}$ are $24.78 \%, 36.29 \%$ and $35.97 \%$ successively. Total $\mathrm{Zn}$ removal efficiencies of tall fescue filter (1\# soil) are $35.28 \%, 30.78 \%$ and $31.48 \%$ successively. Total $\mathrm{Zn}$ removal efficiencies of tall fescue filter (2\# soil) are $24.21 \%, 44.35 \%$ and $51.71 \%$ successively.

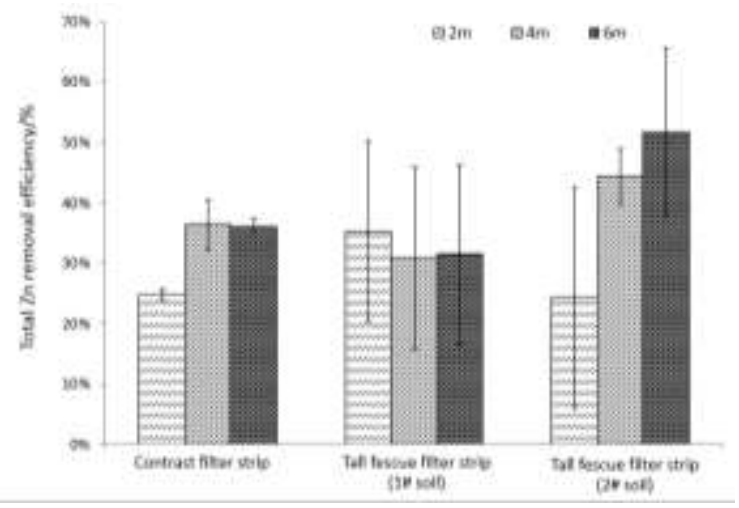

Figure 3. Total $\mathrm{Zn}$ removal efficiencies in surface runoff along $2 \mathrm{~m}, 4 \mathrm{~m}$, and $6 \mathrm{~m}$ of strip.
The result is shown that the total $\mathrm{Zn}$ removal efficiencies of contrast filter strip and tall fescue filter strip (with 2\# soil) have the trend of increasing with the filter width increasing. But the tall fescue filter strip with 1 \# soil does have the trend. It is same as total $\mathrm{Cu}$ interception that $0-4 \mathrm{~m}$ is considered to be the main range of strip width for interception.

Adopting the method of spss17.0 one-way analysis of variance to compare the $\mathrm{Zn}$ removal efficiency of $6 \mathrm{~m}$ filter strip, it is found that there is no significant difference $(p=0.167)$ between contrast filter strip and tall fescue filter strip (A with 1\# soil). But the removal of tall fescue filter strip with $2 \#$ soil is significantly better than tall fescue filter strip with $1 \#$ soil $(p<0.05)$. It can be drawn that vegetation condition is not a significant factor to total $\mathrm{Zn}$ removal efficiency, but soil condition is a significant factor. The soil with higher organic matter content has the higher removal efficiency. In addition, $\mathrm{Zn}$ content of $2 \#$ soil is $59 \mathrm{mg} \mathrm{Kg}-1$, which is lower than that of $1 \#$ soil $\left(156 \mathrm{mg} \mathrm{Kg}^{-1}\right)$. The soil owning lower $\mathrm{Zn}$ content has the greater adsorption capacity, which might be one of the reasons that affect the removal efficiency of filter strip.

The total content of heavy metals in surface runoff is determined, which includes adsorbed heavy metals and heavy metal ion. The inflow concentration of total $\mathrm{Cu}$ is $68.76 \sim 99.23 \mu \mathrm{g} \mathrm{L}^{-1}$ and that of total $\mathrm{Zn}$ is $267.95 \sim$ $496.00 \mu \mathrm{g} \mathrm{L}^{-1}$. The inflow concentration of $\mathrm{Cu}^{2+}$ is $4.310 \sim$ $9.737 \mu \mathrm{g} \mathrm{L}^{-1}$ and that of $\mathrm{Zn}^{2+}$ is $24.885 \sim 81.901 \mu \mathrm{g} \mathrm{L}^{-1}$. By comparison of $\mathrm{Cu}$ and $\mathrm{Zn}$, it is found that ion component has smaller proportion in total content, with $\mathrm{Cu}^{2+}$ accounting for $6.27 \% \sim 9.81 \%$ and $\mathrm{Zn}^{2+}$ accounting for $9.29 \% \sim 16.51 \%$. Therefore, the heavy metal adsorbed with sediment is the main existence in inflow water.

When water flows through the filter system consisting of soil and vegetation, the pollutants get preliminarily intercepted by physical and chemical processes like deposition, filtration, adsorption within a short retention time. And the intercepted pollutants will be transformed further by plant absorption, microbial metabolism and chemical reaction [19-20].

The vegetation is a necessary element of filter strip system, which can block the surface runoff and reduce the speed of runoff. So vegetation can promote particles deposition and the adsorbed pollutant retention. The retention time will be extended, which promotes the interception between pollutants and adsorption sites [2122]. In addition, the plant tissue can contact with runoff, which can produce adsorption to heavy metal. The growth of vegetation can increase the content of organic matter in soil, which is conductive to the adsorption reaction.

Comparing the effects of soil conditions, it can be concluded that $\mathrm{Zn}$ in tall fescue filter strip (2\# soil) is significantly higher than tall fescue filter strip (1\# soil), while the soil has no significant effect on removal efficiency of $\mathrm{Cu}$. The organic matter content of $1 \#$ soil was $5.86 \sim 6.90 \mathrm{~g} \mathrm{Kg}^{-1}$ and that of $2 \#$ soil is $11.62 \sim 13.92$ $\mathrm{g} \mathrm{Kg}^{-1}$. The content of organic matter of soil $2 \#$ is significantly higher than that of soil $1 \#(p<0.01)$. Except organic matters, the caption exchange capacity (CEC) 
and clay proportion of $2 \#$ soil are also higher than those of soil 1\#. And the condition mentioned above is conductive to the adsorption reaction [23-24].

\subsection{Analysis of interception characteristics of heavy metals in subsurface runoff}

The grass filter strip system constructed between pollution source and receiving water can change the hydraulic characteristics of surface runoff. Vegetation barrier and soil percolation can slow surface runoff, and the hydraulic retention time is extended. All the above can promote surface runoff to infiltrate. Therefore, soil percolation is an important way for filter strip to intercept pollutants. In this study, seepage water samples are collected from bottom holes, and the interception effect of heavy metal during seepage through $0.35 \mathrm{~m}$ of soil layer is studied.

The interception effect of total amount heavy metal and heavy metal ion are investigated in this section. The removal efficiencies of total $\mathrm{Cu}$ and $\mathrm{Cu}^{2+}$ in water of $6 \mathrm{~m}$ outlet is shown in Figure 4. Total $\mathrm{Cu}$ removal efficiencies of contrast filter strip, tall fescue filter strip (1\# soil) and tall fescue filter strip (2\# soil) are $96.16 \%, 96.50 \%$ and $95.62 \%$ successively. And those of $\mathrm{Cu}^{2+}$ are $56.31 \%$, $76.23 \%$ and $74.55 \%$ successively. Adopting the spss 17.0 one-way analysis of variance to compare the total $\mathrm{Cu}$ removal efficiencies, it can be drawn that there is no significant difference $(\mathrm{p}=0.825)$ between contrast filter strip and tall fescue filter strip. But $\mathrm{Cu}^{2+}$ removal efficiency of tall fescue filter strip is significantly higher than contrast filter strip $(p<0.05$. There is no significant difference of total $\mathrm{Cu}$ and $\mathrm{Cu}^{2+}$ removal efficiencies in both tall fescue filter strips ( $\mathrm{p}=0.845$ and $\mathrm{p}=0.727$ ).

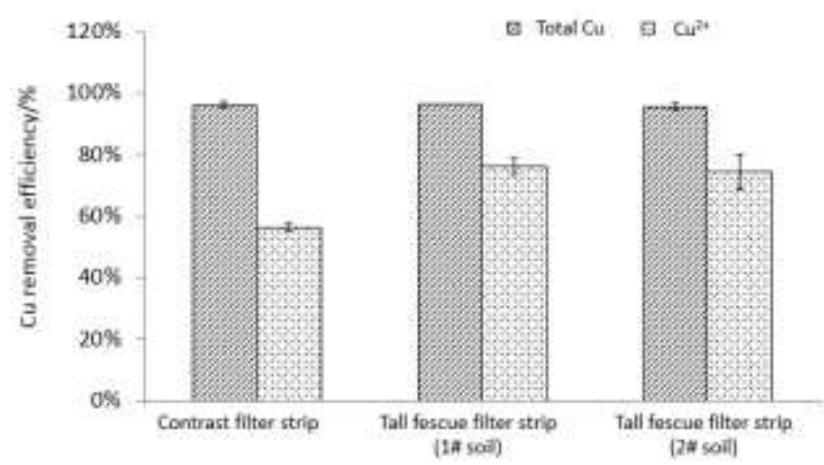

Figure 4. Cu removal efficiencies in subsurface runoff of $6 \mathrm{~m}$ strip.

The removal efficiencies of total $\mathrm{Zn}$ and $\mathrm{Zn}^{2+}$ are shown in Figure 5. Total $\mathrm{Zn}$ removal efficiencies of contrast filter strip, tall fescue filter strip (1\# soil) and tall fescue filter strip (2\# soil) are $99.70 \%, 96.57 \%$ and $95.38 \%$ successively. And the removal efficiencies of $\mathrm{Zn}^{2+}$ are $62.68 \%, 81.43 \%$ and $86.42 \%$ successively.

Adopting the spss 17.0 one-way analysis of variance to compare the total $\mathrm{Zn}$ removal efficiencies, it can be drawn that there is no significant difference $(p=0.869)$ between contrast filter strip and tall fescue filter strip. But $\mathrm{Zn}^{2+}$ removal efficiency of tall fescue filter strip is significantly higher than contrast filter strip $(p<0.05)$.
There is no significant difference of total $\mathrm{Zn}$ removal efficiency in both tall fescue filter strip ( $\mathrm{p}=902)$, but $\mathrm{Zn}^{2+}$ removal efficiency of strip with $2 \#$ soil is significantly higher than that of strip with $1 \#$ soil $(\mathrm{p}<0.05)$.

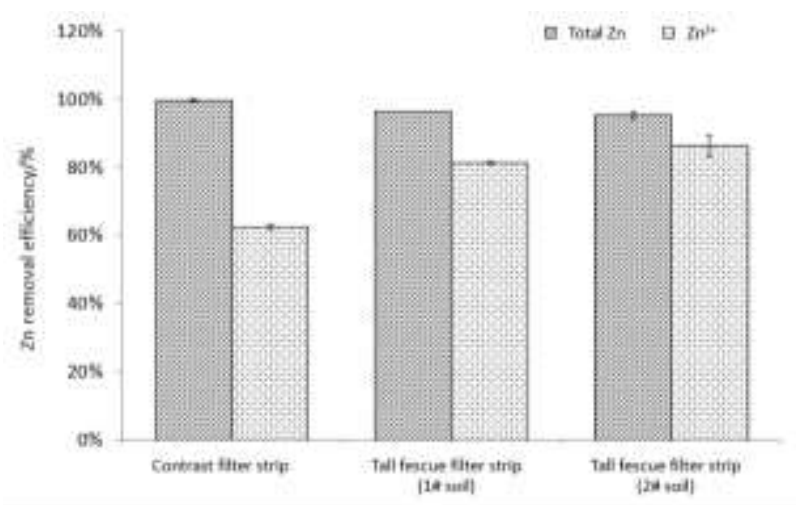

Figure 5. $\mathrm{Zn}$ removal efficiencies in subsurface runoff of $6 \mathrm{~m}$ strip.

Based on the analysis above, it can be drawn that the interception of $\mathrm{Cu}$ and $\mathrm{Zn}$ in $0.35 \mathrm{~m}$ of soil layer are similar. For the total amount of heavy metal, the vegetation condition and soil condition are not significant factors. For heavy metal ion, vegetation condition is an significant factor, and the existence of vegetation is advantageous to the interception of $\mathrm{Cu}$ and $\mathrm{Zn}$ ions. The soil condition is a significant factor to $\mathrm{Zn}^{2+}$, and $2 \#$ soil is more advantageous to the interception of $\mathrm{Zn}^{2+}$.

Total heavy metal includes heavy metal ion and the absorbed heavy metal, and the absorbed one takes on a greater proportion. During the process of water infiltration, most of suspended matters can not seepage through the soil pore, and has been intercepted at the soil layer. Therefore, there is no significant difference for total heavy metal interception in different conditions of vegetation and soil. And the total heavy metal removal efficiency can reach to above $95.38 \%$, which is significantly higher than corresponding ion. The interception process of heavy metal ions through the soil infiltration is more complicated, which including the physical and chemical processes like soil adsorption and desorption, vegetation adsorption and microbial metabolism [25-28]. But within a short term of hydraulic retention, the adsorption and desorption should be a more important process. The water electrical conductivity of surface runoff is around $585.5 \sim 655.5 \mu \mathrm{s} \mathrm{cm}^{-1}$, while the seepage water electrical conductivity is $424.0 \sim 526.5 \mu \mathrm{s}$ $\mathrm{cm}^{-1}$, and there is no significant difference $(\mathrm{p}=0.856)$ between different vegetation and soil conditions. The change of water electrical conductivity shows the process mentioned above are less, such as mineralization of organic matter, biodegradation and caption exchange, that can increase the number of ions in solution. While the adsorption that can decrease the ion number may be the main process to reduce electrical conductivity, which is also verify that adsorption effect is the primary mechanism in penetration process.

\section{Conclusion}


(1) The interception characteristics of total heavy metal are investigated in surface runoff. Adsorbed state is the main existence form of heavy metal in surface runoff, and their interceptions are occurred mainly in the length of 0 $4 \mathrm{~m}$. The removal is slowing down with length increasing from $4 \mathrm{~m}$ to $6 \mathrm{~m}$. The conditions of vegetation and soil have different effects on total $\mathrm{Cu}$ and total $\mathrm{Zn}$ removal. Vegetation has no significant effect on both heavy metals removal, but the soil with higher content of organic matter is contributing to the interception of total $\mathrm{Zn}$.

(2) The interception characteristics of total heavy metal and heavy metal ions are investigated in subsurface runoff. By the seepage of $0.35 \mathrm{~m}$ of soil layer, the removal efficiencies of total $\mathrm{Cu}$ and total $\mathrm{Zn}$ can reach to above $95.38 \%$, which is significantly higher than corresponding ions, and both vegetation and soil conditions have no significant effects. For ions, vegetation is contributing to $\mathrm{Cu}^{2+}$ and $\mathrm{Zn}^{2+}$ removal significantly. Soil condition is only a significant factor to $\mathrm{Zn}^{2+}$, with higher content of organic matter as contributing factor.

\section{Acknowledgements}

This research was supported by the National Water Pollution Control and Treatment Science and Technology Major Project, Grant NO. 2013ZX07104-004.

\section{References}

1. Xiong Deng :J. ACTA SCIENTIARUM NATURALIUM UNIVERSITATIS SUNYATSENI. 146, 244-247, (2007) (In Chinese)

2. SergiSabater, Andrea Butturini, Jean-Christophe Clement, et al. J. Ecosystems, 6, 20-30, (2003)

3. T.J.Schmitt,M.G.Dosskey, K.D.Hoagland. J. Journal of Environmental Quality, 28, 1479-1489 (1999)

4. Jon E. Schoonover, Karl W.J. Williard, James J. Zaczek, et al.J. Agroforestry Systems, 64, 169-180, (2005)

5. Patty, L., B.Rheal, et al. J. Pesticide Science, 49, 243-251 (1997)

6. Dillaha,T.A., R.B. Reneau, et al. J. USEPA, Chesapeake Bay Liaison Office, Annapolis,MD,(1987)

7. Magette, W.L., R.B. Brinsfield, R.E. Palmer, and J.D. Wood.J. Trans. ASAE. 32. 663-667, (1989)

8. Humberto Blanco-Canqui, C. J. Gantzer, S. H. Anderson, E. E. Alberts, and A. L. Thompson . J. Soil Sci. Soc. Am. 68,1670-1678, (2004)
9. Lee, K.H., T.M. Isenhart, R.C. Schultz, and S.K. Mickelson. J. Trans. ASAE. 39, 2231-2239, (1999)

10. Coyne, M.S., R.A. Gilfillen, R.W. Rhodes, and R.L. Blevins. J. Soil Water Conserv. 50,405-408 (1995)

11. Eghball, B., J.E. Gilley, L.A. Kramer, and T.B. J. Soil Water Conserv. 55, 172-176, (2000)

12. Monica Vianello, CostantinoVischetti, Luciano Scarponi, Giuseppe Zanin. J. Chemosphere. 61, 717725, (2005)

13. Mankin KR, Ngandu DM, Barden CJ, Hutchinson SL, Geyer WA. J. Journal of the American Water Resources Association. 43, 1108-1116, (2007)

14. Schultz, R.C., Colletti, J.P., Isenhart, T.M., Simpkins, W.W., Mize, C.W.,Thompson, M.L., J. Agroforestry Syst. 29, 201-226, (1995)

15. Lowrance, R., G. Vellidis, R. D. Wauchope, P. Gay, and D. D.Bosch. J. Trans. ASAE 40, 1047-1057, (1997)

16. Doyle, R. C., Stanton, G. C., and Wolfe, D. C. J. American Society of Agricultural Engineers. 9, 2451-2501, (1977)

17. R.B.Daniels,J.W.Gilliam. J. Soil Science. 60, 246251, (1993)

18. Dayi Lin. Soil experimental guidance. M.China Forestry Press. 37, (2004), (In Chinese)

19. Songlin Zhang, QingshiDong,XibinZhou,et al. J. Journal of Lanzhou University(Natural Sciences). 44, 47-50,(2008)

20. Bailey Ann Sullivan.. Kansas State University, 2006

21. Toshiro Yamada, Sally D.Logsdon, Mark D.Tomer, Michael R.Burkart.J. Environment. 385, 297-309, (2007)

22. Dosskey,Dosskey, M.G., Helmers, M.J., Eisenhauer, D.E., Frantia, T.G. \&Hoagland, K.D. J.Journal of Soil and Water Conservation, 57, 336-343, (2002)

23. Lowrance R., Dabney S. and Schultz R. J. Soil Water Conserv. 57, 36-43, (2002)

24. Standard examination methods for water and wastewater (the 4th edition). M.China (2002)(In Chinese)

25. Lena B.-M., Gilles P , Ann F . J. Landscape Urban Plan. 31, 323 - 331, (1995)

26. Majed Abu-Zreig,Ramesh $P$ Rudra, Hugh R. Whiteley. J. Journal of Environmental Quality. 32, 613-619, (2003)

27. Dillaha,T.A.Reneau, R.B. J. Transactions of the American Society of Agricultural Engineers. 32, 513-519 (1989)

28. Broersma K., Robertson J.H. and Chanasyk D.S. J. Soil Sci Plant Anal. 26, 1795-1811, (1995) 